\title{
DRY GRASSLANDS OF SOUTHERN EUROPE: SYNTAXONOMY, MANAGEMENT AND CONSERVATION
}

\author{
Iva APOSTOLOVA ${ }^{1}$, Jürgen DENGLER ${ }^{2,3, *}$, Romeo DI PIETRO ${ }^{4}$, \\ Rosario G. GAVILÁN ${ }^{5} \&$ Ioannis TSIRIPIDIS ${ }^{6}$
}

\begin{abstract}
The Mediterranean area is a natural biodiversity hotspot that has also been influenced by humans for millennia. Especially the grasslands of Southern Europe have long been known for their diversity and beauty. However, several gaps remain in our knowledge about these grasslands, e.g. for some regions such as the southern Balkans, or taxonomic groups such as cryptogams. Here we introduce a Special Issue with contributions from the $9^{\text {th }}$ European Dry Grassland Group meeting held in Prespa, Greece, 2012. The topic of this meeting was "Dry grasslands of Europe: grazing and ecosystem services" with special focus on Southern European regions. The Special Issue, apart from this Editorial, consists of eight contributions arranged according to the three major topics: syntaxonomy (5 articles), management (2) and conservation (1). The classification papers include descriptions of four new associations and four subassociations. Data about management practices are provided as well. We conclude that dry grassland vegetation in Southern Europe exhibits transitions between different higher syntaxa and thus requires further studies at broader scales to allow better understanding at the supranational scale.

Keywords: Elyno-Seslerietea, European Dry Grassland Group (EDGG), Festuco-Brometea, grazing, Helianthemetea guttati, Koelerio-Corynephoretea, Mediterranean, Molinio-Arrhenatheretea.

\section{Izvleček}

Mediteran je naravna vroča točka biodiverzitete, na katero je človek tisočletja močno vplival. Po svoji raznolikosti in lepoti so še posebej že dolgo znana travišča južne Evrope, vendar so v poznavanju teh travišč prisotne številne vrzeli na območju južnega Balkana ali posameznih taksonomskih skupin, kot so kriptogami. Predstavljamo posebno številko s prispevki z 9. srečanja Evropske skupine za suha travišča (European Dry Grassland Group), ki je bilo leta 2012 v mestu Prespa (Grčija). Tema srečanja je bila "Suha travišča Evrope: paša in ekosistemske storitve" s posebnim poudarkom na območjih južne Evrope. Posebno številko poleg tega uvodnika sestavlja osem prispevkov, ki smo jih uredili v tri glavne teme: sintaksonomijo (5 člankov), gospodarjenje (2) in ohranjanje travišč (1). Članki o klasifikaciji vsebujejo opise štirih novih asociacij in štirih subasociacij. Prav tako vsebujejo podatke o načinu gospodarjenja. Zaključimo lahko, da kaže vegetacija suhih travišč v južni Evropi prehod med različnimi višjimi sintaksoni in zato so potrebne nadaljnje raziskave v večjem merilu, ki bodo omogočile boljše razumevanje v nadnacionalnem merilu.

Ključne besede: Elyno-Seslerietea, Evropska skupina za suha travišča (EDGG), Festuco-Brometea, paša, Helianthemetea guttati, Koelerio-Corynephoretea, Mediteran, Molinio-Arrhenatheretea.
\end{abstract}

${ }^{1}$ Institute of Biodiversity and Ecosystem Research, Bulgarian Academy of Sciences, 23 Acad. Georgi Bonshev str., 1113 Sofia, Bulgaria, iva.apostolova@gmail.com

${ }^{2}$ Disturbance Ecology, Bayreuth Center of Ecology and Environmental Research (BayCEER), University of Bayreuth, Universitätsstr. 30, 95447 Bayreuth, Germany, juergen.dengler@uni-bayreuth.de

* Corresponding author

${ }^{3}$ Synthesis Centre (sDiv), German Centre for Integrative Biodiversity Research (iDiv) Halle-Jena-Leipzig, Deutscher Platz 5e, 04103 Leipzig, Germany

${ }^{4}$ Phytogeography and Applied Geobotany, Dipartimento DATA, "Sapienza" Università di Roma, Via Flaminia 72, 00196 Roma, Italy, romeo.dipietro@uniroma1.it

${ }^{5}$ Departamento de Biología Vegetal II, Facultad de Farmacia, Universidad Complutense, 28040 Madrid, Spain, rgavilan@ucm.es

${ }^{6}$ School of Biology, Aristotle University of Thessaloniki, P. O. Box 104, 54124, Greece, tsiripid@bio.auth.gr 


\section{INTRODUCTION}

The territories of Southern Europe have been influenced by human land use for millennia, giving rise to many secondary types of grasslands at the expense of forests (Kaligarič et al. 2006, Blondel et al. 2010, Klötzli et al. 2010). In addition to relatively favourable climatic conditions (even during the Pleistocene glaciations) and the diverse landscape with many isolated mountains and islands, this human influence has contributed to the present-day diversity of the Mediterranean Basin in general and specifically to the smallscale richness of its grasslands. It is well-known that the Mediterranean region is a biodiversity hotspot and particularly rich in endemic species (Myers et al. 2000, Mittermeier et al. 2004). Many of these species inhabit dry grasslands and are nowadays threatened throughout Europe because of abandonment of traditional use, afforestation, eutrophication, invasions of neophytes or transformation of lands to other uses (Poschlod \& WallisDeVries 2002, Janišová et al. 2012, Vrahnakis et al. 2013a).

Since dry grasslands are adapted to dry and warm conditions, in addition to pontic (steppic) and de-alpine elements, species of Mediterranean and sub-Mediterranean origin contribute significantly to their composition even in regions far from Southern Europe (e.g. Pott 1996, Rosén \& Borgegård 1999). Being exotic in their species composition, rarer and at the same time subject to faster deterioration, dry grasslands in temperate and hemiboreal Europe became a focus of nature conservation much earlier than in Southern Europe, where they still cover relatively huge areas. This is evidenced by several review publications summarising the knowledge on dry grassland conservation in Central, Western and Northern Europe (e.g. Bobbink \& Willems 1993, Willems 2001, Poschlod \& WallisDeVries 2002, Pärtel et al. 2005, Schwabe \& Kratochwil 2009), but not Southern Europe. Also in recent edited volumes on (dry) grassland conservation and management, Southern Europe was largely underrepresented (e.g. Veen et al. 2009, Baumbach \& Pfützenreuter 2013). Accordingly, the ecology and biodiversity of dry grasslands in Southern Europe are not as well-known as for the rest of the continent, and this is particularly true for their management and conservation (but see e.g. Montserrat \& Fillat 1990 for the Iberian Peninsula, Römermann et al. 2005 for S France, Škornik et al. 2010 for Slovenia, Vassilev et al. 2011 for Bulgaria).

The European Dry Grassland Group (EDGG; http://www.edgg.org) was founded in 2008 to represent researchers and conservationists dealing with dry grasslands and steppes in Europe and the whole Palaearctic (see Vrahnakis et al. 2013a). While the previous conferences of the EDGG were all conducted in Central European countries, the 9th European Dry Grassland Meeting took place in Prespa, Greece, from 19 to 23 May 2012 (Vrahnakis et al. 2013b, Fig. 1). In addition to its traditional Special Feature in Tuexenia (Becker et al. 2013), during this conference the EDGG initiated the first complete Special Issue in an international journal exclusively devoted to the dry grasslands in the sub-Mediterranean and Mediterranean regions of Europe, which we are happy to introduce here.

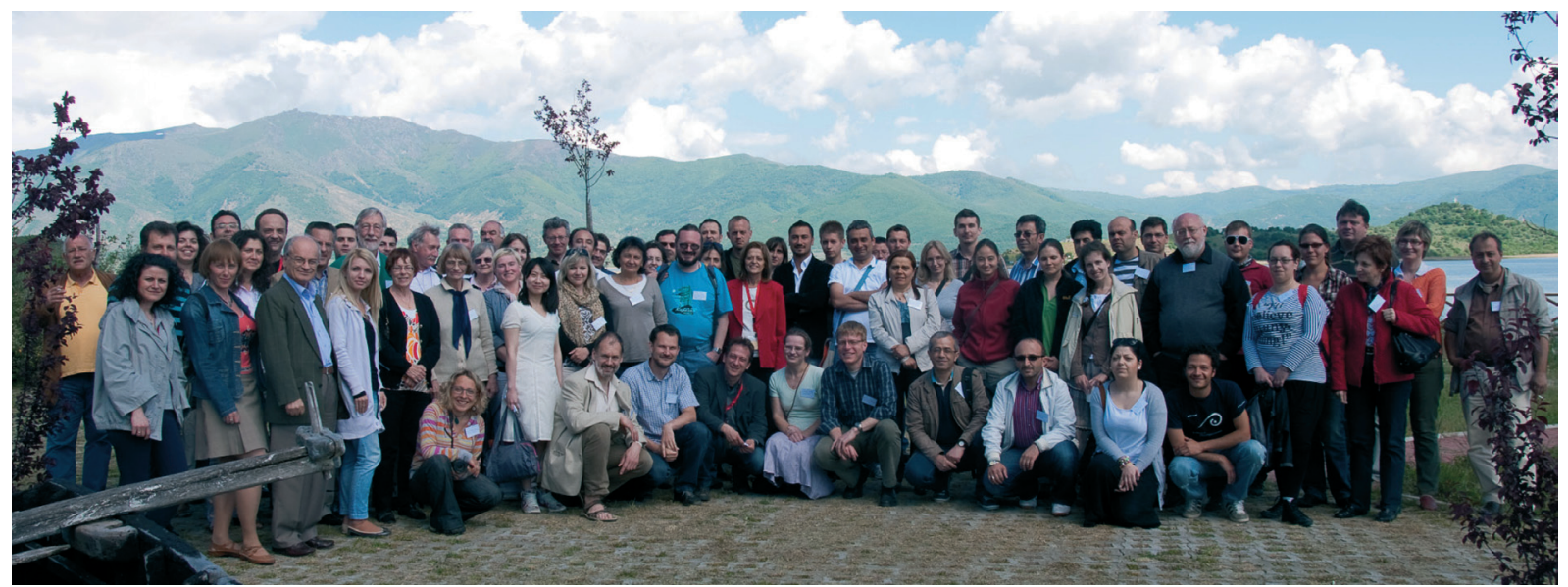

Figure 1: Participants of the 9th European Dry Grassland Meeting, May 2012, in Prespa, Greece. Slika 1: Udeleženci 9. srečanja Skupine za suha travišča (EDGG) maja 2012 v Prespi (Grčija). 


\section{MEDITERRANEAN AND SUB-MEDITERRANEAN DRY GRASSLANDS}

\section{ORIGIN AND DIVERSITY}

The present vegetation of the Mediterranean Basin is the consequence of past changes in climate characteristics (to a higher aridity) and strong variations in the level of the Mediterranean Sea. Both contributed to important plant migrations (López González 2001), which brought e.g. eastern steppic species to western Mediterranean areas, where they now form part of the floristic composition of dry grasslands. The increasing aridity during the Pliocene in Southern Europe favoured the development of species adapted to long arid periods, as typical for present-day Mediterranean climate. Plants modified their leaves and stems, increased the number of hairs, or changed their life form from perennial to annual, allowing them to survive the dry season as seeds. During the Pleistocene, the Mediterranean flora became enriched in alpine and boreal species, which nowadays can be found as elements of high mountain dry grasslands.

At present, the Mediterranean Basin is the largest of the five Mediterranean-type zonobiomes in the world and links Europe, Africa and Asia (Walter 1994). It includes the three main South European peninsulas (the Iberian, Italian and Balkan) the northern Maghreb, the SW part of Anatolia up to the eastern limit of the Mediterranean Sea in the Middle East. The Mediterranean Basin's exceptional concentration of endemic species led to its inclusion among the 25 main hotspots of biodiversity in the world (Myers et al. 2000, Mittermeier et al. 2004).

Mediterranean and sub-Mediterranean dry grasslands are composed of herbaceous vegetation communities mostly dominated by perennial or annual grasses, or more rarely by forbs, that inhabit climatically or edaphically dry sites characterized by poorly developed soils. Typical Mediterranean dry grasslands are those developed under a Mediterranean climate (especially within thermo- and meso-Mediterranean thermotypes) while those defined as "sub-Mediterranean" occur in intermediate areas, which, although broadly classified as "temperate", still exhibit the sharp drop in summer precipitation typical of the Mediterranean climate. In the Mediterranean area, dry grasslands only rarely belong to the natural zonal vegetation (e.g. open grasslands of the subalpine and alpine belt of the Apennines and the Balkans dominated by Sesleria spp.; see Blasi et al. 2003, 2005, Redžić 2003, Surina \& Dakskobler 2005, Di Pietro 2010, Lancioni et al. 2011). Sometimes dry grasslands occur as azonal or extrazonal vegetation (e.g. the Lygeum spartum communities of the salty-clayey "badlands" or the therophytic communities developed on rocky outcrops and travertine crusts). However, most of the Mediterranean dry grasslands are semi-natural, dynamically linked to scrubland and forests. Some of these secondary dry grasslands are dominated by strictly steno-Mediterranean species and are therefore geographically restricted to the Mediterranean Basin (e.g. Cymbopogon hirtus or the Ampelodesmos mauritanicus steppe-like grasslands substituting the former evergreen Quercus ilex woods or the Pistacia lentiscus and Myrtus communis maquis). In other cases, the secondary dry grasslands dynamically replacing deciduous woodlands may exhibit floristic and physiognomical features that are similar to stands in Central Europe (e.g. the Bromus-Koeleria-Festuca communities of the hilly and montane belt).

Recently, certain European dry grasslands have been recognised as the world record holders of vascular plant species richness for spatial grain sizes below $100 \mathrm{~m}^{2}$ (Wilson et al. 2012). While many potential mechanisms are being discussed that could lead to such exceptional small-scale diversity, it is still not well understood which of these are the most relevant and how they interact (Merunková et al. 2012, Dengler et al. 2014). It is well-known that certain temperate and hemiboreal dry grassland types also host an extraordinary plot-scale richness of bryophytes and lichens, which, together with the vascular plants, can reach 140 species at $100 \mathrm{~m}^{2}$ (Dengler $\&$ Boch 2008). The Mediterranean region is much richer in plant species at larger scales than temperate and northern Europe, and particularly in drought-adapted species. It is therefore possible that the higher species pool there might result in small-scale species richness that even exceeds the values of the more northern record holders (White Carpathians, Transylvania and hemiboreal alvars). This speculation cannot, however, be answered at present since there are only very few comparable datasets of scale-dependent plant diversity patterns from the Mediterranean region (de Bello et al. 2007, Giladi et al. 2011). So far, 
no scale-dependent richness values have been presented that are higher than those published in Wilson et al. (2012), either from the Mediterranean Basin or from anywhere else. To our knowledge, there are also no published studies from Southern Europe that have systematically compared diversity patterns of vascular and nonvascular plants. This is a considerable knowledge gap, as such an approach reveals much about the underlying ecological mechanisms due to the different biology of spermatophytes, bryophytes and lichens (Löbel et al. 2006, Turtureanu et al. 2014). New insights here will hopefully become available in the near future, when the data of the EDGG Research Expeditions from Sicily, Greece and Spain (see Guarino et al. 2013, Vrahnakis et al. 2013a) have been analysed.

\section{SyNTAXONOMY}

According to the overview of higher syntaxa in Europe by Rodwell et al. (2002), the dry grasslands in Southern Europe belong to 15 phytosociological classes. Specific Mediterranean grassland classes are the Stipo giganteae-Agrostietea castellanae (meso- to supramediterranean perennial grasslands), the Helianthemetea guttati (Mediterranean annual grasslands) and the Thero-Brachypodietea ramosi (Mediterranean pseudo-steppes and perennial grasslands). Moreover, in the sub-Mediterranean climatic zone and in the medium to higher altitudes of Mediterranean mountains, "temperate" dry grassland classes such as Festuco-Brometea (basiphilous dry grasslands) and Koelerio-Corynephoretea (dry grasslands of sandy and shallow skeletal soils) are widespread, as are the more mesophilous classes Molinio-Arrhenatheretea (mesophilous and wet grasslands) and the Calluno-Ulicetea (acidic grasslands and heathlands), which contain also some meso-xeric types. Finally, there are three widespread classes of arctic-alpine grasslands (Elyno-Seslerietea, Carici rupestris-Kobresietea bellardii, Juncetea trifidi) as well as five geographically restricted ones of oro-Mediterranean grasslands (Festucetea indigestae, Festuco hystricis-Ononidetea striatae, Carici caryophylleae-Genistetea salzmannii, Saginetea piliferae and Daphno-Festucetea). When including Anatolia in the Eastern part of the Mediterranean Basin, several additional dry grassland classes must be considered, namely Astragalo-Brometea, Alchemillo-Campanuletea tridentatae and Alchemillo retin-
ervis-Sibbaldietea parviflorae (Parolly 2004). However, the delimitation of these classes from the European or Eurosiberian classes is not always clear, in particular for the first class.

While most of the Southern European countries have relatively recent checklists of the syntaxa for their territory (e.g. Rivas-Martínez et al. 2002 for Spain and Portugal, Bardat et al. 2004 for France, Biondi et al. 1995b and Bracco et al. 2007 for Italy, Šilc \& Čarni 2012 for Slovenia, Kojić et al. 1998 for Serbia, Tzonev et al. 2009 for Bulgaria and Dimopoulos et al. 1995 for Greece), the syntaxonomic viewpoints in these countries are still largely idiosyncratic. One reason for this is that the syntaxonomic overviews of Southern Europe are so far not based on comprehensive plot databases for delimitation of vegetation units and statistical determination of diagnostic species, unlike the situation in Central and Western Europe (e.g. Rodwell 1992, Schaminée et al. 1996, Berg et al. 2004, Chytrý 2007, Janišová 2007). However, some initial supra-regional or even supra-national data-driven revisions of major grassland syntaxa have been published recently, albeit rather for mesic and saline than for dry types (Eliáš et al. 2013, Rodríguez-Rojo \& Fernández-González in press, Šilc et al. in press).

There are still many syntaxonomic problems of dry grasslands s.l. in Southern Europe that are awaiting satisfactory solutions. For example, the delimitation of some of the classes is not always clear, as certain communities exhibit intermediate features between two or more of them (e.g. the Brachypodium retusum communities of the central Mediterranean intermediate between Lygeo-Stipetea and Thero Brachypodietea, or the alpine Sesleria spp. communities of the southern Balkans between Elyno-Seslerietea and Daphno-Festucetea). A particularly complicated question is whether to place the dry grassland rich in chamaephytes (or: chamaephytic garrigues rich in hemicryptophytes), such as the alliances Saturejion subspicatae, Artemisio-Saturejion and Saturejion montanae, rather in the Festuco-Brometea (Horvatić 1973, Mucina et al. 2009) or the Rosmarinetea (CistoMicromerietea) (Pirone \& Tammaro 1997, Biondi et al. 2005, Di Pietro \& Misano 2010). For Iberia and southern France, authors in a similar situation have proposed a specific intermediate class with a combination of chamaephytic/hemicryptophytic features, Festuco hystricis-Ononidetea striatae (Rivas-Martínez et al. 1991). However, one might question whether establishing highest- 
ranked syntaxa for such transitional types is an appropriate solution. Royer (1991), for example, concluded that the assemblages of the FestucoOnonidetea fit well within the class Festuco-Brometea, an approach also followed by Bardat et al. (2004). Also highly disputed is the placement of the Thero-Airetalia, an order of sandy dry grasslands with subatlantic-submediterranean distribution. Authors from the Netherlands, Germany, Czech Republic and Poland usually include them (or their contents) in the "temperate" class Koelerio-Corynephoretea (Schaminée et al. 1996, Berg et al. 2004, Chytrý 2007, Kącki et al. 2013), while Iberian and French authors prefer to place such communities in the "Mediterranean" class Helianthemetea guttati (Rivas-Martínez et al. 2002, Bardat et al. 2004), and it is indeed hard to decide where to draw the border (e.g. Dengler 2004).

There are also several co-existing but inconsistent concepts of subdivision within the dry grassland classes. This problem is particularly prominent in the Festuco-Brometea, where the traditional concept was to subdivide them into several geographically vicariant orders, such as Brometalia erecti (subatlantic-submediterranean), Festucetalia valesiacae (pontic) and Scorzonero-Chrysopogonetalia (illyric), as masterly elaborated by Royer (1991). More recent overviews from central Europe (Mucina \& Kolbek 1993, Berg et al. 2004, Dengler et al. 2012) prefer a mainly ecological subdivision at the ordinal rank, with the Brachypodietalia pinnati (= Brometalia erecti nom. ambig. propos.) comprising the meso-xeric types throughout Europe, which are characterised by a large number of shared species, the Festucetalia valesiacae the continental steppes and steppe-like grasslands and the Stipo pulcherrimae-Festucetalia pallentis the rocky and dealpine types of the peri-Pannonian region. This concept is in conflict with the traditional subdivision of the class, which is still in use in most parts of Southern Europe, particularly as the order name Brometalia erecti can now mean two very different things: subatlantic-submediterranean basiphilous grasslands of all types or mesoxeric basiphilous grasslands throughout Europe. As a first step to sort out these problems, Mucina et al. (2009) introduced the new order Artemisio albi-Brometalia erecti to comprise the xeric communities of SW Germany, France and Italy, as a counterpart to the continental Festucetalia valesiacae. Subsequently, Di Pietro (2011) and Ubaldi (2011) proposed the establishment of an endemic syntaxon (at the rank of suborder and order, respectively) for the basiphilous dry grasslands of the central and southern Apennines due to the frequent occurrence of endemic dominant species. For the Balkan Peninsula, two regional orders of the Festuco-Brometea have traditionally been used: Astragalo onobrychidis-Potentilletalia (central Balkans) and Scorzonero villosae-Chrysopogonetalia grylli (Illyrian region) (e.g. Redžić 1999). However, Pedashenko et al. (2013) argued that the traditional alliances of the Astragalo-Potentilletalia should instead be distributed between different existing orders based on their floristic composition and ecology: Saturejion montanae to the Stipo pulcherrimae-Festucetalia pallentis, Chrysopogono grylli-Danthonion calycinae to the Brachypodietalia pinnati and Armerio rumeliciPotentillion even to the Trifolio arvensis-Festucetalia ovinae of the class Koelerio-Corynephoretea. Likewise, the mesoxeric alliances Scorzonerion villosae and Hypochaeridion maculatae of the ScorzoneroChrysopogonetalia would fit into the Brachypodietalia pinnati, leaving the question of what to do with the remaining xerophytic alliances ChrysopogonoSaturejion and Saturejion subspicatae. These considerations add just another layer of complexity to the long-standing debate on the southern and eastern limit of the Scorzonero-Chrysopogonetalia as well as its possible occurrence on the other side of the Adriatic Sea (Bonin 1978, Royer 1991, Biondi et al. 1995a, Terzi et al. 2010, Di Pietro 2011, Terzi 2011, Biondi \& Galdenzi 2012).

Finally, a particular issue of dry grassland classification are bryophytes and lichens. While it is well-known that they play an important role in the differentiation of dry grassland syntaxa at all levels (e.g. Dierßen 2001, Berg \& Dengler 2005, Löbel \& Dengler 2008) they are hardly ever recorded in relevés of Southern European dry grasslands, except in rare occasions when central European phytosociologists took relevés there (e.g. BraunBlanquet 1967, Dengler 2004). This practice is in remarkable contrast to the recommendation of the International Code of Phytosociological Nomenclature (Weber et al. 2000) that syntaxa should be based on complete phytocoenoses, not on single synusiae. Since the knowledge on the role of nonvascular plants for the characterisation and differentiation of dry grassland syntaxa in Southern Europe is thus rudimentary (e.g. the rough assessments of the diagnostic value of bryophytes by Dierßen 2001), the EDGG Research Expeditions aim at contributing to filling this knowledge gap (2012 - Sicily: Guarino et al. 2012; 2012 - Greece; 2014 - Spain). 


\section{MANAGEMENT AND CONSERVATION}

Dry grasslands are important stages in secondary successions. In the past, the indiscriminate clearing of the Mediterranean evergreen forests for grazing and the frequent occurrence of wild and man-induced fires have enormously increased the steppe-like landscapes at the expense of maquis or forests. For centuries, the rural economy of hilly and mountainous areas of the Mediterranean region was based upon "traditional" land use patterns. The socio-economic changes which followed the end of the Second World War and the increasing establishment of large-scale intensive agriculture have led to a sharp decline in the number of people involved in traditional agricultural activities and to the consequent abandonment of millions of hectares of previously cultivated areas, leading to so-called "field-succession" which occurs in arable fields after abandonment. This phenomenon has caused a rapid metamorphosis of the landscape, especially within the sub-Mediterranean hilly belt, where the spontaneous recovery by native vegetation is relatively fast. Dry grasslands are an important stage in these secondary successions on abandoned arable fields. If soils are deep and there is little disturbance, these grasslands are substituted by scrublands within few years. This happens, for example, with abandoned terraced olive groves, a typical Mediterranean "vanishing" landscape. The terraces help to retain soil, facilitating the rapid establishment of shrubby communities and accelerating the development towards later successional stages (Blasi et al. 2000, Di Pietro \& Blasi 2002). In contrast, if the abandoned areas remain subject to disturbance (trampling, fire or light grazing), grassland communities may remain "stable" for a protracted period before being replaced by woody vegetation.

There are many ecological services dry grasslands habitats provide: they play an important role in maintaining a high rate of biodiversity at different scales; they constitute a habitat for many endangered species, especially where the traditional silvo-pastoral land-use patterns have been abandoned and the woody communities (secondary shrublands and climax woodlands) are rapidly recolonizing their potential areas; they provide reserve grazing lands up to the late summer when most of the grasslands have dried up under the Mediterranean climate. This latter service was particularly important for the economy and culture of the Mediterranean popula- tions, as it was the basis for transhumance practices, where the shepherds drove their herds from the coastal plains to the mountain areas in the search of green pastures.

In the past, dry grasslands were viewed mainly as the results of degradation from other plant communities and thus of lesser conservation or economic value. The low conservation value assigned to dry grasslands can be attributed to the focus on criteria such as naturalness and stability of ecosystems (see Margules \& Usher 1981). On the basis of such criteria, dry grasslands were scored lower than other vegetation types, as they are in many cases the result of secondary succession. Furthermore, in the past decades there was a much greater need for pastures and arable land in the (sub-) montane areas, as the human population density in those areas was also much higher than today. Moreover, the economy was based more in the production of the primary sector (production based on the use of natural resources).

However, the last two to three decades the scene has been reversed. Large parts of the countryside have been abandoned by man or are used with much lower intensity. The loss of disturbance has already led to the replacement of dry grassland by other vegetation types (e.g. scrub communities) through natural succession. Nowadays, conservationists in Europe are aware that one important threat to biodiversity in the $21^{\text {st }}$ century will be the loss of habitats caused by natural succession of vegetation, which takes place after the cessation of traditional types of land use (see MacDonald et al. 2000, Falcucci et al. 2007, Moreira \& Russo 2007). The high conservation value of dry grasslands has been recognized and many of these are conservation habitat types listed by the European Union's Habitats Directive (92/43/EEG). Its Annex I includes several priority habitats belonging to "Natural and seminatural grassland formations", which, although not restricted to Southern Europe, have their highest coenological diversity there. A classic example of this is the priority habitat 6210 "Semi-natural dry grasslands and scrubland facies on calcareous substrates (Festuco-Brometalia) important orchid sites*", which in the Mediterranean area is extraordinarily rich in orchids of the genera Ophrys, Orchis, Neotinea and Serapias. Floristic differences between the Mediterranean and temperate stands of some dry grassland habitat types according to EU legislation often resulted in misinterpretations of the meaning of the type, and objective difficulties in assigning 
certain stands to a proper category. Another example is the habitat 6110* "Rupicolous calcareous or basophilic grasslands of the Alysso-Sedion albi", which in Southern Europe is very rich in annual Mediterranean species, leading to overlaps with the definition with another Mediterranean priority habitat (6220* Pseudo-steppe with grasses and annuals of the Thero-Brachypodietea).

\section{CONTRIBUTIONS OF THE SPECIAL ISSUE}

This Special Issue further consists of eight contributions from Italy (Foggi et al. 2014), Serbia (with comparison to other western Balkan countries: Kabaš et al. 2014), Bulgaria (Sopotlieva \& Apostolova 2014, Velev \& Vassilev 2014), Greece (Evangelou et al. 2014, Fotiadis et al. 2014, Pirini et al. 2014), as well as Russia and Kazakhstan (Demina \& Bragina 2014). In the following, we briefly introduce them grouped into three major topics: syntaxonomy (5 articles), management (2) and conservation (1).

\section{SYNTAXONOMY}

Foggi et al. (2014) studied Festuco-Brometea grasslands in central Italy on sandstone and marl-claysandstone substrata. Most of the sampled communities were dominated by Bromus erectus. The Festuco trachyphyllae-Brometum erecti is described as a new association. Lower-rank variability within the Centaureo bracteatae-Brometum erecti was recognised in form of three subassociations: a new linetosum cathartici, a typicum and a ononidetosum masquillierii. The authors mention the presence of transgressive species for other vegetation types, namely Koelerio-Corynephoretea and Helianthemetea guttatae.

Kabaš et al. (2014) deal with grasslands dominated by Sesleria juncifolia agg. in the Balkans, which is both taxonomically and syntaxonomically challenging (see Di Pietro et al. 2013, Di Pietro \& Wagensommer 2014). They compared their own relevés from two locations in Serbia with similar stands from neighbouring countries and concluded that they represent two new associations, one to be placed in the Elyno-Seslerietea (alliance Oxytropidion urumovii) and one in the Festuco-Brometea (alliance Chrysopogono-Saturejion). While providing valuable new plot data, this study is limited by the fact that there is little consensus about the classification of dry grasslands on the Balkans (see some points mentioned in Section 2.2) and as yet no single large-scale analysis has established syntaxa and diagnostic species based on a comprehensive dataset with modern statistical methods.

The study of Sopotlieva \& Apostolova (2014) provides a detailed phytosociological classification of the dry grassland vegetation in southeastern Bulgaria. It contributes to the syntaxonomic conspectus of south-eastern Europe by the description of the new association Trifolio arvensis-Festucetum valesiacae. It has transitional character between the Festuco-Brometea and KoelerioCorynephoretea, evidenced by the presence of diagnostic species of both classes. Further, a new subassociation is described within the Euphorbio myrsinitae-Bothriochloetum, differentiated by the Balkan endemic Medicago rhodopaea and mostly limited to limestone areas. Sopotlieva \& Apostolova (2014) found evidence for transitions between classes in grasslands in a relatively small area on the virtual geographical border between the Festuco-Brometea and Thero-Brachypodietea. They provide an example of how the floristic composition and other vegetation attributes of syntaxa are affected when they appear at the limits of their distribution. Further, they show how vegetation classification can be treated in areas comprising transition zones between different plant-geographical regions. Considering that species composition as well as spatial arrangement of dry grassland plant communities are sensitive to environmental changes, especially at the borders of their geographical distribution, the data and the results of the work of Sopotlieva \& Apostolova (2014) offers a sound and useful basis for monitoring the impacts of climate changes on vegetation (see Parton et al. 1994, Duckworth et al. 2000a, Duckworth et al. 2000b).

Pirini et al. (2014) present new data on the low-altitude dry calcareous grasslands of a sector in northern Greece where the phytosociological information was very scarce before. Despite the occurrence of three different taxa of the genus Stipa, the steppe-like grasslands of the area were not considered as a relict of the steppic vegetation spread during the Pleistocene but as secondary degradation stages of the forest vegetation. In syntaxonomical terms, the authors employed the order Astragalo-Potentilletalia (compare Section 2.2) to encompass syntaxa intermediate between the continental Festucetalia valesiacae, the eastern 
sub-Mediterranean Scorzonero-Chysopogonetalia and the central Mediterranean Thero-Brachypodiet$e a$ (for a contrasting viewpoint, see Pedashenko et al. 2013, who suggest the dissolution of the order Astragalo-Potentilletalia). Probably the Chrysopogon gryllus-Bothriochloa ischaemum communities have the highest similarities with the ScorzoneroChrysopogonetalia communities of the Northwest Dinarids whereas the Stipa capillata-Koeleria macrantha communities exhibit stronger links to the Festucetalia valesiacae communities of the northeastern sector of the Balkans. Some amphi-Adriatic floristic similarities were identified towards dry grasslands communities of the Italian peninsula, which, although characterized by the same dominant species, are currently included in different high-rank syntaxa. The inclusion of the Northern Greek Artemisia alba and Satureja montana communities in the Festuco-Brometea whereas the Italian counterparts are currently included in the Rosmarinetea/Cisto-Micromerietea (Allegrezza et al. 1997, Pirone \& Tammaro 1997, Di Pietro \& Misano 2010) is symptomatic of the lack of a shared point of view amongst the phytosociologists, in the syntaxonomical classification of the Mediterranean micro-chamaephytic-hemicryptophytic grasslands.

Finally, among the syntaxonomic papers, that of Fotiadis et al. (2014) is to some extent an "excursion guide" for the European Dry Grassland Meeting in Prespa since it describes the main grassland types in the surroundings of the venue, most of which the participants also saw during the excursions. Due to the manifold geology and the large altitudinal range, the grasslands of the Prespa region are quite diverse. This is reflected by the fact that the authors assign them to six different phytosociological classes. The article particularly focusses on the first Greek record of the Sileno conicae-Cerastion semidecandri/Bromion tectorum-Bassion laniflorae (Festuco-Sedetalia acris, Koelerio-Corynephoretea), which is an EU priority habitat type.

\section{Management}

Traditional management of grasslands in the studied regions is mowing and grazing, which depends on the primary production and accessibility. Historically, management practices and intensities have varied. Therefore, there is an urgent need to understand and monitor the changes in grass- land vegetation in relation to the changes in the management regimes. The work of Velev \& Vassilev (2014) addresses this topic by investigating the changes of management regimes in syntaxa of mesic and dry grasslands. Their work is based on a large number of relevés and covers a large area of western Bulgaria. The authors ascertain the significant decrease of livestock farming in Bulgaria during the last two decades. Their work highlights differences in management practices between the mesic and dry grasslands as well as in the percentage values of abandoned areas between the phytosociological alliances recognized in the area. Further, they found significant differences in the diversity between grasslands with different management regimes within each syntaxon. Thus, their work provides new and interesting data on the consequences of land-use changes on attributes of vegetation of widespread syntaxa (alliances) of mesic and dry grasslands. In Bulgaria, dry grasslands of the alliances Cirsio-Brachypodion, Festucion valesiacae and Chrysopogono-Danthonion are predominantly managed as pastures, while $M o$ linio-Arrhenatheretea meadows represented by the Cynosurion and Arrhenatherion are mostly subject to mowing or a combined usage. Preservation of the traditional extensive way of management is stated as highly important for biodiversity conservation.

Studies on the behaviour of grazing animals enable implementation of proper regime and measures for both nature conservation and economic value of the grasslands. Such information is provided by Evangelou et al. (2014) for the sheep and goat grazing regimes in northern Greece. Both animals are commonly used as domestic stock in the Balkans. Extensive farming and differentiated resources provided by the rangelands and agricultural land is seen as most effective for the sustainable farming. The authors consider a heterogeneous landscape as necessary for supporting extensive farming since rangelands and agricultural lands complement each other in providing forage throughout the year.

\section{Conservation}

Natural steppes of Eastern Europe have suffered from intense management practices, leading to changes in floristic composition, serious fragmentation and even complete regional disappearance. Demina \& Bragina (2014) contribute to the knowledge on diversity and provide guidance for 
conservation prioritization for Eurasian steppes, based on studies in the Don basin (European part of Russia) and Tobol-Turgai basin (Asian part of Kazakhstan). First, the authors provide an overview how red-listed plant species are distributed within the 37 distinguished steppe associations (classes Festuco-Brometea, Festucetea vaginatae, Helianthemo-Thymetea and Festuco-Puccinellietea) of the Russian study area and perform a conservation assessment of the phytosociological units. Then they assess the invertebrate diversity of three coarsely delimited steppe types in the Kazakh study area.

\section{CONCLUSIONS AND OUTLOOK}

The papers in this Special Issue provide new information about the Southern European dry grassland vegetation, its management and conservation. Four new associations and four subassociations are published for the first time here. The included syntaxonomic papers frequently emphasize the transitional character of the studied syntaxa and/or problems with placing them into the syntaxonomic system. This reflects the fact that Southern Europe, unlike many areas in Central and West Europe, still largely lacks largescale data-driven revisions of its vegetation types. While the vegetation of Iberian and Italian Peninsulas have been intensively documented in the past century by means of regional studies and national syntaxonomic overviews, the dry grasslands of large parts of the Balkan Peninsula, southern Ukraine and Russia as well as Anatolia are much less well-known despite the fact that they cover huge areas and host a significant part of the overall biodiversity of the Mediterranean region s.l.

The presentations at the EDGG meeting in Prespa (see Vrahnakis et al. 2013b), including those published in this Special Issue, expand current knowledge on dry grassland communities, but also demonstrate the need for further studies at broader scales to come to convincing conclusions. The intensive international collaborations recently initiated by EDGG, among others, are very promising in this respect. For example, quite recently national and supranational databases of all vegetation types (e.g. Landucci et al. 2012 for Italy, Apostolova et al. 2012 for Bulgaria and Dimopolous et al. 2012 for Greece) and specifically for dry grasslands (e.g. Vassilev et al. 2012 for the Balkan Peninsula and Uğurlu \& İşik 2012 for Turkey) have been established, which themselves contribute to the European Vegetation Archive (EVA; http://euroveg.org/eva-database; see Jiménez-Alfaro et al. 2013). Such national to continental databases will facilitate not only large-scale consistent classifications of grassland vegetation types (see Dengler et al. 2013), but also enable a better understanding of diversity patterns and assembly rules in grassland and provide invaluable baseline information for grassland conservation (see Dengler et al. 2011). Likewise, the EDGG Research Expeditions conducted in various regions of Europe whose grasslands are little documented by standardised methods, and increasingly so in Southern European venues, aim at contributing to filling important knowledge gaps through joint international efforts (see Vrahnakis et al. 2013b).

It was a great pleasure for us to write this Editorial to this Hacquetia Special Issue on dry grasslands of Southern Europe. There is probably not a single vegetation scientist or botanist in general who could light-heartedly claim not feeling overwhelmingly attracted by this habitat type, extraordinary in species and landscape diversity, colours, fragrances and history. In a Mediterranean dry grassland you are somehow obliged to collect data. There is not a specific reason for why it happens. Sometimes just because your mind unconsciously asks for an immediate evaluation of that overflowing diversity. In other cases because you feel that all those shapes and colours must necessarily hide something of new, a species, a process, a gradient ... Or simply because the weather is nice and you feel happy.

\section{ACKNOWLEDGEMENTS}

This Special Issue was initiated at the 9th European Dry Grassland Meeting, organised 2012 by Michael Vrahnakis on behalf of the European Dry Grassland Group (EDGG) and the Hellenic Range and Pasture Society (HERPAS) in Prespa, Greece. We are grateful to Urban Šilc for offering Hacquetia as publication venue and leaving us great freedom in preparing the Special Issue, to the authors for submitting interesting manuscripts on a variety of topics, to many reviewers who, through their competent suggestions, helped to improve the quality of the content, to Aiko Huckauf and Laura Sutcliffe for linguistic editing of the articles and finally to EDGG for financial support through an IAVS project grant. 


\section{REFERENCES}

Allegrezza, M., Biondi, E., Formica, E. \& Ballelli, S. 1997: La vegetazione dei settori rupestri calcarei dell'Italia centrale. Fitosociologia 32: 91-120.

Apostolova, I., Sopotlieva, D., Pedashenko, H., Velev, N. \& Vassilev, K. 2012: Bulgarian Vegetation Database: historic background, current status and future prospects. Biodiversity \& Ecology 4: 141-148.

Bardat, J., Bioret, F., Botineau, M., Boullet, V., Delpech, R., Géhu, J.-M., Haury, J., Lacoste, A., Rameau, J.-C., Royer, J.-M., Roux, G. \& Touffet, J. 2004: Prodrome des végétations de France. - Patrimoines Naturels 61: 1-171.

Baumbach, H., Pfützenreuter, S. (eds.) 2013: Steppenlebensräume Europas - Gefährdung, Erhaltungsmaßnahmen und Schutz. TMLFUN, Erfurt, 456 pp.

Becker, T., Reitalu, T., Ruprecht, E. \& Dengler, J. 2013: Dry grassland of Europe: biodiversity, classification, conservation and management - Editorial to the 8th Dry Grassland Special Feature. Tuexenia 33: 285-291.

Berg, C. \& Dengler, J. 2005: Moose und Flechten als diagnostische Arten von Pflanzengesellschaften - eine Übersicht aus MecklenburgVorpommern. Herzogia 18: 145-161.

Berg, C., Dengler, J., Abdank, A. \& Isermann, M. (eds.) 2004: Die Pflanzengesellschaften Mecklenburg-Vorpommerns und ihre Gefährdung - Textband. Weissdorn, Jena, 606 pp.

Biondi, E., Ballelli, S., Allegrezza, M. \& Zuccarello, V. 2005a: La vegetazione dell'ordine Brometalia erecti Br.-Bl. 1936 nell'Appennino (Italia). Fitosociologia 30: 3-45.

Biondi, E., Bracco, F. \& Nola, O. 1995b: Lista delle unita sintassonomiche della vegetazione Italiana. Fitosociologia 32: 1-227.

Biondi, E., Allegrezza, M. \& Zuccarello, V. 2005: Syntaxonomic revision of the Apennine grasslands belonging to Brometalia erecti, and an analysis of their relationships with the xerophilous vegetation of Rosmarinetea officinalis (Italy). Phytocoenologia 35: 129-164.

Biondi, E. \& Galdenzi, D. 2012: Phytosociological analysis of the grasslands of Montagna dei Fiori (central Italy) and syntaxonomic review of the class Festuco-Brometea in the Apennines. Plant Sociology 49: 91-112. Blasi, C., Di Pietro, R. \& Fortini, P., 2000: A phytosociological analysis of abandoned terraced olive grove shrublands in the Tyrrhenian district of Central Italy. Plant Biosystems 134: 305-331.

Blasi, C., Di Pietro, R., Fortini, P. \& Catonica, C. 2003: The main plant community types of the alpine belt of the Apennine chain. Plant Biosystems 137: 83-110.

Blasi, C., Di Pietro, R. \& Pelino, G. 2005: The vegetation and landscape of alpine belt karsttectonic basin in the Majella mountain (central Apennines). Plant Biosystems 139: 357-385.

Blondel, J., Aronson, J., Bodiou, J.-Y. \& Boeuf, G. 2010: The Meditrerranean Region - Biological diversity in space and time. 2nd ed. Oxford University Press, Oxford, 376 pp.

Bobbink, R. \& Willems, J. H. 1993: Restoration management of abandoned chalk grassland in the Netherlands. Biodiversity and Conservation 2: 616-626.

Bonin, G. 1978: Contribution à la connaissance de la végétation des montagnes de l'Apennin centro-meridional. Thesis, University of Marseille, $318 \mathrm{pp}$.

Bracco, F., Panfili, E., Sburlino, G. \& Venanzoni,R. 2007. Il secondo aggiornamento della lista sintassonomica italiana (2000-2004). Fitosociologia 44, Suppl. 1: 5-12.

Braun-Blanquet, J. 1967: Vegetationsskizzen aus dem Baskenland mit Ausblicken auf das weitere Ibero-Atlantikum. II. Teil. Vegetatio 14: 1-126.

Chytrý, M. (ed.) 2007: Vegetation of the Czech Republic -1 . Grassland and heathland vegetation [in Czech, with English summary]. Academia, Praha, 526 pp.

de Bello, F., Lepš, J. \&Sebastià, M.-T. 2007: Grazing effects on the species-area relationship: Variation along a climatic gradient in $\mathrm{NE}$ Spain. Journal of Vegtation Science 18: 25-34.

Demina, O. \& Bragina, T. 2014: Fundamental basis for the conservation of biodiversity of the Black Sea-Kazakh steppes. Hacquetia 13: 215-228.

Dengler, J. 2004: Artenzusammensetzung und Phytodiversität von Trockenrasen auf Granitgrus entlang eines Höhentransektes in der Serra da Estrela (Portugal). Kieler Notizen zur Pflanzenkunde in Schleswig-Holstein und Hamburg 32: 49-56.

Dengler, J. \& Boch, S. 2008: Sampling-design effects on properties of species-area curves - A case study from Estonian dry grassland communities. Folia Geobotanica 43: 289-304.

Dengler, J., Jansen, F., Glöckler, F., Peet, R. K., De Cáceres, M., Chytrý, M., Ewald, J., Oldeland, J., Lopez-Gonzalez, G., Finckh, M., Mu- 
cina, L., Rodwell, J. S., Schaminée, J. H. J. \& Spencer, N. 2011: The Global Index of Vegetation-Plot Databases (GIVD): a new resource for vegetation science. Journal of Vegetation Science 22: 582-597.

Dengler, J., Becker, T., Ruprecht, E., Szabó, A., Becker, U., Beldean, M., Bita-Nicolae, C., Dolnik, C., Goia, I., Peyrat, J., Sutcliffe, L. M. E., Turtureanu, P. D. \& Uğurlu, E. 2012: Festuco-Brometea communities of the Transylvanian Plateau (Romania) - a preliminary overview on syntaxonomy, ecology, and biodiversity. Tuexenia 32: 319-359.

Dengler, J., Bergmeier, E., Willner, W. \& Chytrý, M. 2013: Towards a consistent classification of European grasslands. Applied Vegetation Science 16: 518-520.

Dengler, J., Janišová, M., Török, P. \& Wellstein, C. 2014: Biodiversity of Palaearctic grasslands: a synthesis. Agriculture, Ecosystems and Environment 182: 1-14.

Di Pietro, R. \& Blasi, C. 2002: A phytosociological analysis of abandoned olive groves grasslands of Ausoni mountains (Tyrrhenian district of Central Italy). Lazaroa 23: 79-93.

Di Pietro, R. 2010: Phytosociological features of Sesleria calabrica (Poaceae), an endemic species of Pollino-Orsomarso mountains (southern Italy). Acta Botanica Gallica 157: 539-554.

Di Pietro, R. \& Misano, G. 2010: Shrublands and garrigue vegetation in the "Gravine" gorges (Apulia region, south-eastern Italy). Acta Botanica Gallica 157: 195-229.

Di Pietro, R. 2011. New dry grassland associations from the Ausoni-Aurunci mountains (Central Italy) - Syntaxonomical updating and discussion on higher rank syntax. Hacquetia 10: 183-231.

Di Pietro, R., Kuzmanović, N., Iamonico, D., Pignotti, L., Barina, Z., Lakusić, D. \& Alegro, A. 2013. Typification of names in the Sesleria juncifolia species complex (Poaceae). Phytotaxa 152(1): 18-32

Di Pietro R. \& Wagensommer, R. P. 2014: A new Sesleria juncifolia association from south-eastern Italy and its position in the amphi-Adriatic biogeographical context. Acta Botanica Croatica 173: 171-207.

Dierßen, K. 2001: Distribution, ecological amplitude and phytosociological characterization of European bryophytes. Bryophytorum Bibliotheca 56: 1-289.

Dimopoulos, P., Papagastergiadou, E., Sykora, K., Georgiadis, T., Babalonas, D. \& Dafis, S.
1995: Inventory of phytosociological data on the vegetation of Greece. Goulandris Natural History Museum, Greek Biotope/Wetland Centre, 94 pp.

Dimopoulos, P., Tsiripidis, I., Bergmeier, E., Fotiadis, G., Theodoropulos, K., Raus, T., Panitsa, M., Kalimanis, A. S., Sýkora, K. V. \& Mucina, L. 2012: Towards the Hellenic National Vegetation Database: VegHellas. Plant Sociology 49: 81-87.

Duckworth, J. C., Bunce, R. G. H. \& Malloch, A. J. C. 2000a: Modelling the potential effects of climate change on calcareous grasslands in Atlantic Europe. Journal of Biogeography 27: 347-358.

Duckworth, J. C., Bunce, R. G. H. \& Malloch, A. J. C. 2000b: Vegetation gradients in Atlantic Europe: the use of existing phytosociological data in preliminary investigations on the potential effects of climate change on British vegetation. Global Ecology and Biogeography 9: 187-199.

Eliáš, P. jr., Sopotlieva, D., Díté, D., Hájková, P., Apostolova, I., Senko, D., Melečková, Z. \& Hájek, M. 2013: Vegetation diversity of saltrich grasslands in Southeast Europe. Applied Vegetation Science 16: 521-537.

Evangelou, C., Yiakoulaki, M. \& Papanastasis, V. 2014: Spatio-temporal analysis of sheep and goats grazing in different forage resources of northern Greece. Hacquetia 13: 205-214.

Falcucci, A. Maiorano, L. \& Boitani, L. 2007: Changes in land-use/land-cover patterns in Italy and their implications for biodiversity conservation. Landscape Ecology 22: 617-631.

Fanelli, G. 1998: Dasypyrum villosum vegetation in the territory of Rome. Rendiconti Lincei Scienze Fisiche e Naturali 9: 149-170.

Foggi, B., Lastrucci. L., Gennai, M. \& Viciani, D. 2014: The Festuco-Brometea grasslands on sandstone and marl-clay-sandstone substrata in Tuscany (Northern-central Italy). Hacquetia 13: $19-56$.

Fotiadis, G., Vrahnakis, M., Kazoglou, Y. \& Tsiripidis, I. 2014: Dry grassland types in the Prespa National Park (NW Greece), including the southernmost occurrence of the priority habitat type "Pannonic sand steppes" (code 6260). Hacquetia 13: 171-190.

Giladi, I., Ziv, Y., May, F. \& Jeltsch, F. 2011: Scaledependent determinants of plant species richness in a semi-arid fragmented agro-ecosystem. Journal of Vegetation Science 22: 983-996. 
Guarino, R., Becker, T., Dembicz, I., Dolnik, C., Kacki, Z., Kozub, Ł., Rejžek, M. \& Dengler, J. 2012: Impressions from the 4th EDGG Research Expedition to Sicily: community composition and diversity of Mediterranean grasslands. Bulletin of the European Dry Grassland Group 15: 12-22.

Horvat, I., Glavač, V. \& Ellenberg, H., 1974: Vegetation Südosteuropas. Fischer, Jena, 768 pp.

Horvatić, S. 1973: Syntaxonomic analysis of the vegetation of dry grassland and stony meadows in Eastern Adriatic coastal Karts district based on the latest phytocoenological research. Fragmenta Herbologica Jugoslavica 32: 1-15.

Janišová, M. (ed.) 2007: Grassland vegetation of Slovak Republic - electronic expert system for identification of syntaxa [in Slovak, with English summary]. Botanický ústav SAV, Bratislava, 263 pp. + CD-ROM.

Janišová, M., Bartha, S., Kiehl, K. \& Dengler, J. 2011: Advances in the conservation of dry grasslands - Introduction to contributions from the 7th European Dry Grassland Meeting. Plant Biosystems 145: 507-513.

Jiménez-Alfaro, B., Apostolova, I., Čarni, A., Chytrý, M., Csiky, J., Dengler, J., Dimopoulos, P., Font, X., Golub, V., Hennekens, S., Jandt, U., Jansen, F., Kącki, Z., Kevey, B., Krstonosić, D., Landucci, F., Lysenko, T., Martynenko, V., Mucina, L., Rodwell, J., Schaminée, J., Šibík, J., Šilc, U., Sorokin, A., Stančić, Z., Willner, W. \& Yamalov, S. 2013: Unifying and analysing vegetation-plot databases in Europe: the European Vegetation Archive (EVA) and the Braun-Blanquet project. CAFF Proceedings Report 10: 50-51.

Kabaš, E., Vukojičić, S., Alegro, A., Surina, B., Kuzmanović, N., Šegota, V. \& Lakušić, D. 2014: Numerical evaluation of grasslands dominated by Sesleria juncifolia agg. in Serbia. Hacquetia 13: 57-78.

Kącki, Z., Czarniecka, M. \& Swacha, G. 2013: Statistical determination of diagnostic, constant and dominant species of the higher vegetation units of Poland. Monographiae Botanicae 103: 1-269.

Kaligarič, M., Culiberg, M. \& Kramberger, B. 2006: Recent vegetation history of the North Adriatic Grasslands: expansion and decay of an anthropogenic habitat. Folia Geobotanica 41: 241-258.

Klötzli, F., Dietl, W., Marti, K., Schubiger-Bossard, C. \& Walther, G.-R. (2010): Vegetation
Europas. Das Offenland im vegetationskundlich-ökologischen Überblick unter besonderer Berücksichtigung der Schweiz. Ott, Bern, 1190 pp.

Kojić, M., Popović, R. \& Karadžić, B. 1998: Sintaksonomski pregled vegetacije Srbije. Institut za biološka istraživanja "Siniša Stanković", Beograd. 218 pp.

Lancioni, A., Facchi, J. \& Taffetani, F. 2011: Syntaxonomical analysis of the Kobresio-Myosuroidis-seslerietea caeruleae and Carici Rupestris-Kobresietea Bellardii classes in the central southern Apennines. Fitosociologia 48: 3-21.

Landucci, F., Acosta, A. T. R., Agrillo, E., Attorre, F., Biondi, E., Cambria, V. E., Chiarucci, A., Del Vico, E., De Sanctis, M., Facioni, L., Geri, F., Gigante, D., Guarino, R., Landi, S., Lucarini, D., Panfili, E., Pesaresi, S., Prisco, I., Rosati, L., Spada, F. \& Venanzoni, R. 2012: VegItaly: The Italian collaborative project for a national vegetation database. Plant Biosystems 146: 756-763.

Löbel, S. \& Dengler, J. 2008 [“2007”]: Dry grassland communities on southern Öland: phytosociology, ecology, and diversity. Acta Phytogeographica Suecica 88: 13-31.

Löbel, S., Dengler, J. \& Hobohm, C. 2006: Species richness of vascular plants, bryophytes and lichens in dry grasslands: The effects of environment, landscape structure and competition. Folia Geobotanica 41: 377-393.

López González, G. 2001: Los árboles y arbustos de la Península Ibérica e Islas Baleares. Ediciones Mundi-Prensa, Madrid.

MacDonald, D, Crabtree, J. R, Wiesinger, G., Dax, T., Stamou, N., Fleury, P., Gutierrez Lazpitae, J. \& Gibon, A. 2000: Agricultural abandonment in mountain areas of Europe: Environmental consequences and policy response. Journal of Environmental Management 59: 47-69.

Margules, C. \& Usher, M. B. 1981: Criteria used in assessing wildlife conservation potential: a review. Biological Conservation 21: 79-109.

Merunková, K., Preislerova, Z. \& Chytrý, M. 2012: White Carpathian grasslands: can local ecological factors explain their extraordinary species richness? Preslia 84: 311-325.

Mittermeier, R. A., Gil, P. R., Hoffman, M., Pilgrim, J., Brooks, T., Mittermeier, C. G., Lamoreux, J. \& da Fonseca, G. A. B. 2004: Hotspots revisited: Earth's biologically richest and most endangered terrestrial ecoregions. CEMEX, Mexico City, 392 pp. 
Montserrat, P. \& Fillat, F. 1990: The system of grassland management in Spain. In: Breymeyer, A. I. (ed.): Managed grasslands. Regional studies. Ecosystems of the World 17(2): Elsevier, Amsterdam, pp. 37-70.

Moreira, F. \& Russo, D. 2007: Modelling the impact of agricultural abandonment and wildfires on vertebrate diversity in Mediterranean Europe. Landscape Ecology 22: 1461-1476.

Mucina, L. \& Kolbek, J. 1993: Festuco-Brometea. In: Mucina, L., Grabherr, G. \& Ellmauer, T. (eds.): Die Pflanzengesellschaften Österreichs - Teil I: Anthropogene Vegetation. Fischer, Jena, pp. 420-492.

Mucina, L., Dengler, J., Bergmeier, E., Čarni, A., Dimopoulos, P., Jahn, R. \& Matevski, V. 2009: New and validated high-rank syntaxa from Europe. Lazaroa 30: 267-276.

Myers, N., Mittermeier, R. A., Mittermeier, C. G., Fonseca, G. A. B. \& Kent J. 2000. Biodiversity hotspots for conservation priorities. Nature 403: 853-858.

Parolly, G. 2004: The high mountain vegetation of Turkey - a state of the art report, including a first annotated conspectus of the major syntaxa. Turkish Journal of Botany 28: 39-63.

Pärtel, M., Bruun, H. H. \& Sammul, M. 2005: Biodiversity in temperate European grasslands: origin and conservation. Grassland Science in Europe 10: 1-14.

Parton, W. J., Ojima, D. S. \& Schimel, D. S. 1994: Environmental change in grasslands: assessment using models. Climate Change 28: 111-141.

Pedashenko, H., Apostolova, I., Boch, S., Ganeva, A., Janisová, M., Sopotlieva, D., Todorova, S., Ünal, A., Vassilev, K., Velev, N. \& Dengler, J. 2013: Dry grasslands of NW Bulgarian mountains: first insights into diversity, ecology and syntaxonomy. Tuexenia 33: 309-346.

Pirini, C. B., Tsiripidis, I. \& Bergmeier, E. 2014: Steppe-like grassland vegetation in the hills around the lakes of Vegoritida and Petron, North-Central Greece. Hacquetia 13: 121-170.

Pirone, G. \& Tammaro, F. 1997: The hilly calciophilous garigues in Abruzzo (central Apennines-Italy). Fitosociologia 32: 73-90.

Poschlod, P. \& WallisDeVries, M. 2002: The historical and socioeconomic perspective of calcareous grasslands - lessons from the distant and recent past. Biological Conservation 104: 361-376.

Pott, R. 1996: Die Entwicklungsgeschichte und Verbreitung xerothermer Vegetationseinhei- ten in Mitteleuropa unter dem Einfluß des Menschen. Tuexenia 16: 337-369.

Redžić, S. 1999: The syntaxonomical differentiation of the Festuco-Brometea Br.-Bl. \& R. Tx. 1943 et Klika \& Hadac 1944 in the Balkans. Annali di Botanica 57: 167-180.

Redžić, S. 2003: The syntaxonomy and syngenesis of the Elyno-Seslerietea Br.-Bl. 1948 in the Balkan Peninsula. Annali di Botanica Nuova Serie 3: 53-74.

Rivas-Martínez, S., Díaz, T. E., Prieto, J. A., Loidi, J. \& Penas, A. 1991: Festuco hystricis-Ononidetea striatae y Rosmarinetea officinalis, clases de vegetación independientes. Itinera Geobotanica 5: 505-516.

Rivas-Martínez, S., Díaz, T. E., Fernández-González, F., Izco, J., Loidi, J., Lousa, M. \& Penas, A. 2002: Vascular plant communities of Spain and Portugal. Addenda to the syntaxonomical checklist of 2001. Itinera Geobotanica 15: 1-922.

Rodríguez-Rojo, P. \& Fernández-González, F. in press: Diversity patterns and typology of Cynosurus cristatus grasslands (Cynosurion cristati Tüxen 1947) in the Iberian Peninsula. Folia Geobotanica. DOI: 10.1007/s12224-014-9191-7.

Rodwell, J. S. (ed.) 1992: British plant communities. Volume 3: Grasslands and montane communities. Cambridge University Press, Cambridge, $540 \mathrm{pp}$.

Rodwell, J. S., Schamineé, J. H. J., Mucina, L., Pignatti, S., Dring, J. \& Moss, D. 2002: The diversity of European vegetation - An overview of phytosociological alliances and their relationships to EUNIS habitats. National Reference Centre for Agriculture, Nature and Fisheries, Wageningen, $168 \mathrm{pp}$.

Römermann, C., Dutoit, T., Poschlod, P. \& Buisson, E. 2005: Influence of former cultivation on the unique Mediterranean steppe of France and consequences for conservation management. Biological Conservation 121: 21-33.

Rosén, E. \& Borgegård, S.-O. 1999: The open cultural landscape. Acta Phytogeographica Suecica 84: 113-134.

Royer, J. M. 1991: Synthèse eurosibérienne, phytosociologique et phytogéographique de la classe des Festuco-Brometea. Dissertationes Botanicae 178: 1-296.

Schaminée, J. H. J., Stortelder, A. H. F. \& Weeda, E. J. (eds.) 1996: De Vegetatie von Nederland - Deel 3. Plantengemeenschappen van graslanden, zomen en droge heiden [in Dutch]. Opulus, Uppsala, 360 pp. 
Schwabe, A. \& Kratochwil, A. 2009: Renaturierung von Sandökosystemen im Binnenland. In: Zerbe, S. \& Wiegleb, G. (ed.): Renaturierung von Ökosystemen in Mitteleuropa. Spektrum Akademischer Verlag, Heidelberg, pp. 235-263.

Šilc, U. \& Čarni, A. 2012: Conspectus of vegetation syntaxa in Slovenia. Hacquetia 11: 113-164.

Šilc, U., Aćić, S., Škvorc, Ž., Krstonošić, D., Franjić, J. \& Dajić Stevanović, Z. in press: Grassland vegetation of the Molinio-Arrhenatheretea class in the NW Balkan Peninsula. Applied Vegetation Science. DOI: 10.1111/ avsc.12094.

Škornik, S., Vidrih, M. \& Kaligarič, M. 2010: The effect of grazing pressure on species richness, composition and productivity in North Adriatic Karst pastures. Plant Biosystems 144: 355-364.

Sopotlieva, D. \& Apostolova, I. 2014: Dry grassland vegetation in the transition zone between two biogeographic regions. Hacquetia 13: $79-120$.

Surina, B. \& Dakskobler, I., 2005: Delimitation of the alliances Caricion firmae (Seslerietalia albicantis) and Seslerion juncifoliae (Seslerietaliajuncifoliae) in the southern Alps and Dinaric mountains. Plant Biosystems 139: 399-410.

Terzi, M. 2011: Nomenclatural revision of the order Scorzonero-Chryopogonetalia. Folia Geobotanica 46: 411-444.

Terzi, M., Di Pietro, R. \& D'Amico, F. S. 2010: Analisi delle specie indicatrici applicata alle comunità a Stipa austroitalica Martinovsky e relative problematiche sintassonomiche. Fitosociologia 47: 3-28.

Turtureanu, P. D., Palpurina, S., Becker, T., Dolnik, C., Ruprecht, E.,. Sutcliffe, L. M. E., Szabó, A. \& Dengler, J. 2014: Scale- and taxondependent biodiversity patterns of dry grassland vegetation in Transylvania (Romania). Agriculture, Ecosystems and Environment 182: 15-24.

Tzonev, R., Dimitrov, M. \& Roussakova, V. 2009: Syntaxa according to Braun-Blanquet approach in Bulgaria. Phytologica Balcanica 15: 209-233.

Ubaldi, D. 2011: Le vegetazioni erbacee e gli arbusteti italiani. Aracne, Roma, 361 pp.

Uğurlu, E. \& İşik, D. 2012: Vegetation Database of the Grassland Communities in Anatolia. Biodiversity \& Ecology 4: 313-313. Biocentre Klein Flottbek and Botanical Garden, Hamburg.
Vassilev, K., Pedashenko, H., Nikolov, S., Apostolova, I. \& Dengler, J. 2011: Effect of land abandonement on the vegetation of upland seminatural grasslands in the Western Balkan Mts., Bulgaria. Plant Biosystems 145: 654-665.

Vassilev, K., Dajić, Z., Ćusterevska, R., Bergmeier, E. \& Apostolova, I. 2012: Balkan Dry Grasslands Database. Biodiversity \& Ecology 4: 330-330.

Veen, P., Jefferson, R., de Smidt, J. \& van der Straaten, J. (eds.) 2009: Grasslands in Europe of high nature value. KNNV Publishing, Zeist, 320 pp.

Velev, N. \& Vassilev, K. 2014: Management regimes within syntaxa of semi-natural grasslands in West Bulgaria. Hacquetia 13: 191-204.

Vrahnakis, M. S., Janišová, M., Rūsiņa, S., Török, P., Venn, S. \& Dengler, J. 2013a: The European Dry Grassland Group (EDGG): stewarding Europe's most diverse habitat type. In: Baumbach, H. \& Pfützenreuter, S. (eds.): Steppenlebensräume Europas - Gefährdung, Erhaltungsmaßnahmen und Schutz. TMLFUN, Erfurt, pp. 417-434.

Vrahnakis, M., Kyriazopoulos, A. P., Chouvardas, D. \& Fotiadis, G. (eds.) 2013b: Dry grasslands of Europe: grazing and ecosystem services - Proceedings of the 9th European Dry Grassland Meeting (EDGM) Prespa, Greece, 19-23 May 2012. HERPAS, Thessaloniki, 349 pp.

Walter, H. 1994: Vegetation of the Earth and ecological systems of the geo-biosphere. Springer, Berlin, 318 pp.

Weber, H. E., Moravec, J. \& Theurillat, J.-P. 2000: International Code of Phytosociological Nomenclature. 3rd edition. Journal of Vegetation Science 11: 739-768.

Willems, J. H. 2001: Problems, approaches, and results in restoration of Dutch calcareous grassland during the last 30 years. Restoration Ecology 9: 147-154.

Wilson, J. B., Peet, R. K., Dengler, J. \& Pärtel, M. 2012: Plant species richness: the world records. Journal of Vegetation Science 23: 796-802.

Received: 2. 6. 2014

Accepted: 3. 6. 2014

Co-ordinating editor: Urban Šilc 